Syntax Literate : Jurnal Ilmiah Indonesia p-ISSN: 2541-0849

e-ISSN : 2548-1398

Vol. 4, No. 12 Desember 2019

\title{
PENGARUH KEMAMPUAN DAN KEPUASAN KERJA TERHADAP PRODUKTIVITAS KARYAWAN PADA PABRIK TAHU DI DESA CITEUREUP KECAMATAN KAWALI KABUPATEN CIAMIS
}

\section{Sudibyo Budi Utomo dan Siti Nuraeni}

STIE STMY Majalengka

Email: sudibyobo27@gmail.com dan nur193987@gmail.com

\begin{abstract}
Abstrak
Tujuan penelitian ini adalah untuk menganalisis dan mengetahui pengaruh kemampuan dan kepuasan kerja terhadap produktivitas karyawan.Penelitian ini ditujukan untuk menguji pengaruh Kemampun Kerja dan Kepuasan Kerja terhadap Produktivitas Karyawan baik secara parsial maupun simultan pada Pabrik Tahu di Desa Citeureup Kecamatan Kawali Kabupaten Ciamis. Metode penelitian yang digunakan adalah metode penelitian deskriptif dengan jumlah sampel 25 responden. Data dikumpulkan dengan menggunakan metode kuesioner, dan analisis data yang digunakan adalah analisis regresi berganda, analisis korelasi, koefisien determinasi dan uji hipotesis.Hasil analisis regresi berganda menunjukan bahwa: $Y=11,038+0,178 X_{1}+0,093 X_{2 .}$ Dari persamaan linear berganda di atas, dapat dilihat besarnya konstanta adalah 11,038. Hal ini berarti harga matematis perubahan prduktivitas karyawan( $Y)$ pada saat semua variabel bebasnya nol adalah sebesar 11,038. Koefisien korelasi antara kemampuan dan kepuasan kerja dengan produktivitas karyawan adalah sebesar 0,23. Hal tersebut menunjukkan bahwa hubungan antara ketiga variabel dikatakan cukup. Koefisien determinasi menunjukkan nilai variabel Produktivitas Karyawan 5,3\% ditentukan oleh varian yang terjadi pada Kepuasan Kerja dan Kemampuan Kerja. Dengan demikian, pengaruh Kemampuan Kerja dan Kepuasan Kerja terhadap Produktivitas Karyawan $=5,3 \%$ dan sisanya ditentukan oleh faktor lain. Hasil uji hipotesis menunjukkan bahwa hipotesis pertama dapat dierima, karena t hitung > t tabel untuk uji satu pihak ha ditolak dan ho diterima.
\end{abstract}

Kata kunci: Kemampun Kerja, Kepuasan Kerja, Produktivitas Karyawan

\section{Pendahuluan}

Di era globalisasi ini banyak usaha-usaha yang bersaing ketat di bidangnya masing-masing, mengikuti kemajuan zaman yang semakin meningkat dan berubah-ubah setiap tahunnya. Dalam kemajuannya untuk meningkatkan kualitas serta kuantitasnya, setiap usaha yang dijalankan akan memilih dan memanfaatkan Sumber Daya Alam dan Sumber Daya Manusia yang baik dan teknologi yang canggih. 
Produktivitas ada sesuatu yang berkaitan dengan kemampuan sumber daya manusia dalam organisasi perusahaan. Di samping dikaitkan dengan kemampuan sumber daya manusia, produktivitas juga kerap dikaitkan dengan cara dan sistem yang efisien. Sedang cara dan sistem yang efisien sendiri kerap dihubungkan dengan proses produksi yang tepat waktu, sehingga proses produksi tidak memerlukan kerja lembur dan tambahan biaya. Dengan semua keterkaitan dan hubungan di atas, wajar jika sebuah perusahaan baik itu jasa ataupun pembuat produk- menginginkan sumber daya manusianya untuk senantiasa produktif, khususnya dalam proses produksi dan pelayanan konsumen (Afriandi, 2017)

Sumber Daya Manusia sangatlah berperan penting dalam suatu usaha. Karena itu akan membantu memperkuat dan mempertahankan eksistensi internal yang dimiliki. Terlebih jika Sumber Daya Manusia yang ada memiliki potensi serta ilmu pengetahuan dan teknologi yang baik.

Perkembangan manajeman perusahaan dewasa ini khususnya dalam manajeman sumber daya manusia dipacu dengan adanya tuntutan untuk lebih memperhatikan kebijaksanaan yang akan diterapkan perusahaan terhadap karyawannya. Kebijakan perusahaan yang tidak sesuai dengan kebutuhan dan harapan karyawan akan membawa dampak buruk pada sikap karyawannya.

Pencapaian tujuan perusahaan perlu pengelolaan Sumber Daya Manusia secara efektif dan efisien. Manajeman Sumber Daya Manusia tidak hanya memperhatikan kepentingan perusahaan, akan tetapi juga memperhatikan kebutuhan karyawan dan tuntutan masyarakat luas. Disinalah peran manajeman sumber daya manusia diperlukan untuk memadukan kepentingan-kepentingan tersebut yaitu perusahaan, karyawan dan masyarakat luas untuk tercapainya efektivitas, efesiensi, kemampuan, kepuasan serta produktivitas kerja yang maksimal.

Menurut (Wijono, 2010) mampu adalah: "kesanggupan atau kecakapan, sedangkan kemampuan berarti seseorang yang memiliki kecakapan atau kesanggupan untuk menjalankan sesuatu yang diwujudkan melalui tindakannya untuk meningkatkan produktivitas kerjanya."

Produktivitas kerja merupakan salah satu masalah penting yang harus diperhatikan oleh perusahaan. Perusahaan akan selalu berusaha meningkatkan 
produktivitas kerja karyawan untuk mewujudkan tujuan yang telah digariskan sebelumnya.

Kemampuan kerja sangat mempengaruhi produktivitas kerja, untuk itu pekerja atau karyawan harus mempunyai kemampuan dalam bidangnya untuk melaksankan tugas yang diperintahkan atasan kepadanya agar dapat meningkatkan produktivitas kerja mereka itu sendiri. Produktivitas kerja sendiri merupakan salah satu masalah penting yang harus diperhatikan oleh perusahaan. Perusahaan akan selalu berusaha meningkatkan produktivitas kerja karyawan, untuk mewujudkan tujuan yang telah digariskan sebelumnya. Faktor-faktor yang mempengaruhi produktivitas kerja yaitu kualitas kerja, kuantitas kerja serta ketepatan waktu.

Usaha Pabrik Tahu yang didirikan oleh bapak Sutrisno juga memerlukan kemampuan pegawai yang memadai. Karena dengan kemampuan yang dimiliki oleh para pegawai, maka produktivitas kerja karyawan pun akan tercapai. Selain itu, usaha Pabrik tahu akan dapat bersaing dengan usaha-usaha yang lainnya.

Untuk mencapai tujuan tersebut, harus ada timbal balik antara pegawai dan atasan. Pegawai memberikan prestasi yang baik dan menunjukan kemampuan yang dimiliki, sedangkan atasan menghargai dan memberikan faktor-faktor yang menunjang terciptanya kinerja yang optimal.

Selain kemampuan yang dapat mempengaruhi produktivitas kerja, kepuasan kerjapun sangat mempengaruhi produktivitas kerja. Kepuasan kerja mencerminkan perasaan seseorang terhadap pekerjaannya. Dapat dikatakan bahwa kepuasan merupakan aspek penting. "Secara historis sering dianggap bahwa para karyawan yang mendapatkan kepuasan kerja akan melakukan pekerjaan dengan baik" (Handoko, 2000) Hal tersebut sesuai dengan pendapat (Wijono, 2010) bahwa "kepuasan kerja yang memadai akan memicu semangat serta kreativitas dalam bekerja, sehingga menunjukan kinerja yang baik."

Kepuasan kerja tidak hanya mempengaruhi produktivitas, kepuasan kerja dan produktivitas juga saling berhubungan. (Robbins, 1996) mengemukakan bahwa: "Secara umum karyawan yang puas cenderung akan lebih produktif daripada mereka yang tidak atau kurang puas. Hubungan antara kepuasan kerja dan produktivitas didasarkan pada suatu asumsi bahwa karyawan yang merasa dirinya bahagia adalah karyawan yang produktif." 
Salah satu aspek yang harus diperhatikan oleh usaha Pabrik Tahu yang didirikan oleh Bapak Sutrisno adalah aspek kepuasan kerja karyawan. Karena, apabila atasan mengetahui apakah karyawannya mendapatkan kepuasan atau tidak (insentif, fasilitas dan lingkungan kerja) maka atasan juga akan mendapatkan kepuasan tersendiri. Karyawan puas dengan insentif dan fasilitas yang diberikan serta situasi lingkungan kerja, sedangkan atasan puas karena dapat membuat karyawannya merasa mendapat kepuasan kerja dengan memberikan faktor penentu yang dapat mencapai produktivitas karyawan. Selain itu, perusahaan/usaha juga harus memperhatikan faktor komitmen karyawan, karena dengan komitmen yang baik maka seorang karyawan akan mampu melakukan pekerjaan serta tugas yang dibebankan padanya dengan penuh tanggung jawab serta berusaha melakukan pekerjaan dengan maksimal.

Usaha Pabrik Tahu Bapak Sutrisno memiliki karyawan atau pegawai 25 orang. Pada tahun pertama pegawainya hanya berjumlah 3 orang, kemudian tahun kedua dan tahun-tahun berikutnya terus bertambah hingga sekarang pegawainya berjumlah 25 orang. Adapun data hasil wawancara jumlah peningkatan karyawan Pabrik Tahu Bapak Sutrisno dari tahun ke tahun dalam bentuk tabel.

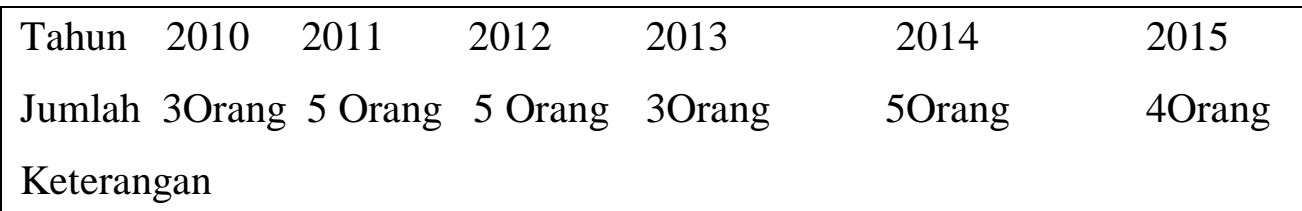

Dengan jumlah karyawan yang sedikit akan mudah untuk melihat dan mengetahui kemampuan serta kepuasan kerja karyawannya dengan berkomunikasi secara langsung dan terbuka antara atasan dan bawahan. Tetapi dengan jumlah yang banyak akan sedikit sulit, maka atasan diharapkan untuk mengadakan pelatihan untuk meningkatkan kemampuan karyawan. Sedangkan untuk meningkatkan kepuasan kerja atasan memberikan semangat dengan cara memotivasi dan memberikan penghargaan atas kerja keras serta kerjasama yang sudah dilakukan oleh karyawan.

Dengan adanya cara-cara tersendiri untuk meningkatkan kemampuan dan kepuasan kerja karyawan, maka produktivitaspun akan tercapai. Karena kemampuan dan kepuasan kerja berkaitan erat dengan produktivitas, meskipun tidak semua faktor yang ada akan mempengaruhi tercapainya produktivitas.

Alasan memilih judul yaitu untuk mengetahui apakah para pegawai Pabrik Tahu Desa Citeureup memiliki kemampuan yang memadai untuk dapat membuat usaha 
tersebut lebih berkembang. Selain itu, apakah pimpinan usaha selalu memberikan motivasi dan semangat kepada para pegawainya, dan dapat membuat pegawainya merasa puas dengan memberikan fasilitas kerja yang mendukung kegiatan kerja.

\section{Metode Penelitian}

Metode yang digunakan dalam penelitian ini adalah metode deskriptif. Metode penelitian deskriptif mempunyai tujuan untuk membuat deskripsi, gambaran atau lukisan secara sistematis, faktual dan akurat mengenai fakta-fakta, sifat-sifat serta hubungan antara fenomena yang diselidiki (Tarsito, 2014).

\section{Hasil Penelitian dan penelitian}

Hasil penelitian menunjukkan bahwa kemampuan dan kepuasan kerja secara bersama-sama memberikan dampak positif terhadap produktivitas karyawan. Kemampuan dan kepuasan kerja secara bersama-sama dapat mempengaruhi produktivitas karyawan, dikarenakan kemampuan kerja terdapat dalam diri sendiri sedangkan kepuasan kerja menunjukkan bahwa pegawai memiliki rasa kepuasan dengan faktor penentu yang diberikan oleh perusahaan untuk mencapai produktivitas.

Hasil analisis menyatakan bahwa hubungan antara kemampuan dan kepuasan kerja dengan produktivitas karyawan dikatakan cukup. Kemampuan dan kepuasan kerja memang memiliki keterkaitan sendiri dengan produktivitas. Kemampuan merupakan salah satu faktor untuk mencapainya suatu produktivitas, sedangkan kepuasan adalah perasaan yang ada pada diri seseorang yang nantinya akan mempengaruhi produktivitas itu sendiri.

Faktor kemampuan karyawan terdiri dari pengetahuan dan keterampilan, dimana pendidikan atau pengetahuan karyawan yang memadai untuk jabatannya dan keterampilan dalam menggerakan pekerjaan sehari-hari, maka karyawan akan lebih mudah mencapai kinerja yang diharapkan (Keith Davis dalam Mangkunegara, 2000:67).

Pengetahuan dan keterampilan sesungguhnya yang mendasari tercapainya produktivitas. Keterampilan adalah kemampuan dan penguasaan teknis operasional mengenai bidang tertentu, yang bersifat kekaryaan. Keterampilan diperoleh melalui. Salah satu hasil penelitian Wicaksono yang dikutif oleh (As'ad, 2002) menunjukan 
bahwa terdapat hubungan yang positif dan signifikan antara kepuasan kerja dan produktivitas kerja. Hal ini menunjukan bahwa, secara umum kepuasan memiliki hubungan dengan produktivitas kerja karyawan. Bagi manajeman organisasi tetap penting untuk mengusahakan hubungan yang positif antara kepuasan dengan produktivitas kerja, meskipun itu tidak mudah (Siagian, 2019)

\section{Kesimpulan}

Kesimpulan yang dapat penulis sampaikan setelah melakukan penelitian dan pembahasan mengenai pengaruh kemampuan dan kepuasan kerja terhadap produktivitas karyawan, maka dapat disimpulkan sebagai berikut :

1. Kemampuan Kerja dan Kepuasan Kerja berpengaruh cukup tinggi terhadap Produktivitas Kayrawan pada Pabrik Tahu Desa Citeureup Kecamatan Kawali Kabupaten Ciamis. Hal tersebut dibuktikan dengan analisis regresi yang menyatakan bahwa nilai kemampuan kerja 0,178 dan nilai kepuasan kerja 0,093 dengan konstanta 11,038. Nilai-nilai tersebut mempengaruhi berkurangnya nilai atau bertambahnya nilai produktivitas karyawan.

2. Berdasarkan hasil analisis didapat nilai Produktivitas Karyawan sebesar 5,3\% ditentukan oleh varian yang terjadi pada Kepuasan Kerja dan Kemampuan Kerja. Dengan demikian, pengaruh Kemampuan Kerja dan Kepuasan Kerja terhadap Produktivitas Karyawan $=5,3 \%$ dan sisanya ditentukan oleh faktor lain.

3. Tingkat kemampuan kerja pada Pabrik Tahu di Desa Citeureup Kecamatan Kawali Kabupaten Ciamis sudah mencapai paling rendah 74,3\% dari yang diharapkan. Tingkat kepuasan kerja paling rendah $71,4 \%$ dan tingkat produktivitas karyawan paling tinggi $75,7 \%$. Hal tersebut dibuktikan dengan uji hipotesis deskriptif yang menyatakan bahwa hipotesis pertama adalah benar. 
Sudibyo Budi Utomo dan Siti Nuraeni

\section{BIBLIOGRAFI}

Afriandi, S. (2017). Meningkatkan Produktivitas Kerja Di Perusahaan Jasa Survey. Syntax Literate; Jurnal Ilmiah Indonesia, 2(2), 133-143.

As'ad, M. (2002). Psikologi industri, seri ilmu sumber daya manusia. Edisi KeEmpat. Yogyakarta: Liberty.

Handoko, T. H. (2000). Manajemen personalia dan manajemen sumber daya manusia. Yogyakarta: BPFE.

Robbins, M. (1996). Conceiving of personality.

Siagian, S. P. (2019). Manajemen sumber daya manusia.

Tarsito, S. (2014). Metode Penelitian Kuantitatif, Kualitatif dan R\&D. Alfabeta. Bandung.

Wijono, S. (2010). Psikologi industri \& organisasi. Kencana. 